\title{
Toward Applying Virtual Reality Technique as a Promotional Tool in Tourism and Hospitality Services in Egypt
}

Salama Ammar Mohamed Wael Mohamed Abd EL Naby

The High Institute for Tourism and Hotels (EGOTH) in Luxor, South Valley University

\section{Abstract}

The current study aimed at activating the Virtual reality technique at tourism and hospitality industry in Egypt. Virtual reality application is one of the recent trends at tourism field in many countries. For example, the United Arab Emirates in November 2016 used virtual reality technique in marketing the tourism and hospitality services across the world. Also, the current study aimed at adopting the technique of virtual reality and its role in the activating international tourism movement. The study used the analytical perspective method. The questionnaire was used as the study tool to be applied on the study sample which consisted of the managers of tourism and hospitality services marketing at the hotels sectors, travels agents in Luxor and a random sample of tourists in Luxor. The study showed the absence of complete understanding and awareness, of virtual reality concept and its application at tourism and hospitality industry for managers of hotels and touristic companies, besides to the confusion between the concepts of virtual reality and e-marketing. Additionally, there is no a weakness and shortage of the provision and availability of virtual reality environment component and its tools in case of touristic collapse and the limited use of virtual reality due to its high cost. The study set a number of recommendations, most important of which is activating the cooperation at the field of hospitality and tourism represented by the Ministry of Tourism besides other ministries and authorities, e.g. Ministries of Communication, environment, and investment.

Keywords: Virtual reality- types of virtual reality- hotel services- tourism servicesperception- virtual reality as a promotion tool.

\section{Introduction}

Nowadays, the world witnesses a great revolution and unprecedented substantial changes at the technological and scientific progress and the era of open skies and clouds within technology and communication systems and etc., resulting in the emergence of the $4^{\text {th }}$ and $5^{\text {th }}$ generation networks. Various challenge such as overcoming the problem of place dimension at tourism and hospitality industry because tourism and hospitality services cannot be evaluated unless they are consumed.Virtual reality is considered as a new pattern of marketing that contribute to accomplishing reality, reliability, and the tangibility in the process of marketing the tourism and hospitality services . It provides an opportunity to experience reality before deciding to travel to a destination and enjoy the various hotel services. Technological development of mass media and communication offers the interaction between the producer and consumer. Additionally, it breaks the barrier between them as the consumer becomes a producer if s/he has the appropriate tools. Traditional methods of Tourist information could be enhanced by VR. VR can serve as an invaluable method of providing necessary information to potential Tourists and, therefore, act as a marketing tool for the Tourism Industry. VR systems have the ability to provide potential tourists with the opportunity to experience destinations and their respective attractions and facilities.

\section{Statement of the problem}

Modern marketing trends give unprecedented interest to modern marketing strategies, such as E-marketing. They greatly perceive applying the strategies of virtual and augmented realities and respond to the requirements of informational technology age besides to cloud and open skies.(WTO,2017). Under modern technology revolution and the $4^{\text {th }}$ and $5^{\text {th }}$ 
generations of internet networks, the consumer of these services needs to be fully aware of the quality and efficiency of the real services provided. However, marketing tourism and hospitality services reality suffers from the weak capabilities of transferring the real mental image in a complete and right way to the outer world. Thus, the role of these realities as marketing alternatives is maximized simultaneously with the intangibility of tourism and hospitality activities and the place dimension that makes marketing a highly difficult issue, especially with the existence of the alternatives of tourism and hospitality services in the different markets across the nearby competitive countries. In other words, using these realities encourage overcoming the previously mentioned difficulties and promote tourism and hospitality services. In this technology, human senses collaborate to produce an experience similar to reality, although it is unreal. Here, some attachments are connected to the computer to enable the individual to see the program in a three-dimensional way. In addition, some tools and devices, such as gloves and headsets are used to enable the individual to touch, feel, see, and hear. Virtual reality programs prepare an environment for the user that allows interaction as if it is a real one. The developed countries tend to attract the largest number of tourists by the distant simulation of reality with all temporal dimensions. Hence, it is a highly impressive technology for the current situation in Egypt.

\section{Objectives of the study}

The current study attempts to achieve a set of objectives, including:

1. Recognizing the concept of virtual reality and its applicability at hospitality and tourism fields in Egypt.

2. Defining the role of virtual and augmented realities as a promotional tool of tourism and hospitality services in Egypt.

3- Measuring the ability of virtual reality technique in decreasing the gap of tourism and hospitality services sensory perception.

\section{Hypotheses of the study}

To achieve the previous purposes, a number of hypotheses have been tested during the present investigation:

H1: There are no significant differences among hotels, tour operators, and travel agents in the application of virtual reality techniques.

$\mathrm{H} 2$ : Tourists are highly satisfied of the virtual reality techniques applied in hotels, tour operators and travel agencies.

H3: Educational qualifications of tourists are significantly affect their use of virtual reality. H4: Tourists age have a significant effect of their use of virtual reality

H5:. Educational qualifications of tourists are significantly affect their level of Satisfaction of virtual reality.

\section{The Study Significance}

The significance of the current study has been defined in the following considerations:

1. It responds to the vision of World Tourism Organization in 2017 to achieve creativity and excellence at marketing tourism and hospitality services through emarketing and virtual and augmented realities.

2. It helps in developing the strategies of tourism and hotels marketing, especially emarketing because using modern techniques, e.g. virtual reality, directly and indirectly help to interact and experience the general atmosphere of the destination by the consumer. 
3. It responds to the most significant developments in a changing and developing world under the third and fourth generations of the Internet and maximizing their benefit in tourism and hospitality industries in Egypt.

4. It consolidates realism, tangibility, and appropriateness methodology. It is a key basis of creativity and excellence in e-marketing of services. That is, tour operators and travel agents and hospitality sector use of virtual reality enriches the process of marketing and achieves self-perception to identify the quality and efficiency of hospitality and tourism services. Virtual reality represents reality as it is. It is an effective means of imitating reality whatever its conditions and difficulty are. Thus, various environments that simulate reality can be shaped, but a person cannot achieve or adapt to. A learner cannot really live in space environment. Accordingly, it is the role of virtual reality to form a similar environment that a person can interact with. If applied to the field of tourism and hospitality, virtual reality greatly affects the perception of services and eradicates one of its main disadvantages, i.e. Intangibility (BLEŠIĆ et al ,2011)and the study aims at activating the virtual reality technique at tourism and hospitality industry in Luxor.

\section{History of virtual reality}

The history of virtual reality dates back tothe German philosopher Immanuel Kant. Although its use was not only limited to technology, it was renewed and refined by Jaron Lanier in 1981. Academically, the term was used only once. However, it was used for a long time under "virtual environment" in the educational field LaVelle (2017). Elsayed Elshafeey (2012) illustrated that many other terms were used, including artificial reality in 1970s, cyberspace Iin 1980s, and virtual environment recently. Nowadays, academicians have preferred to use virtual reality. Xia et al. (2013) argued that virtual reality unprecedented developed and emerged at all aspects of life, including education, engineering, military, industries, medicine, games, and entertainment. Lately, it has achieved great popularity, especially in the process of perceiving production of the various stages and services. Warren and Wakefield (2015) affirmed that it was fertile in education. Therefore, it achieved incomparable speed. For example, USA is a pioneering country at all educational levels in applying this technique. Technology is the vehicle that helps learners create and discover.

\section{The concept of virtual reality}

Zaineldeen (2010) and Sejzi et al. (2012) asserted that virtual reality is a comprehensive environment that is collected and managed by the computer or software where the user logs into and interacts with virtual reality such as play station. Tüma (2014) illustrates that it is a simulation of reality and human activities using the computer and a $3 \mathrm{D}$ environment in which participants appear as if they exist in the real environment. Liu et al. (2015) argue that despite the multiplicity of its definitions, virtual reality's concept is clear. That is, it creates confidence via real and correct reflections of the product or services; an imaginary symbolization. Furthermore, it is a strong tool to evaluate products and services by really embodying them.

\section{The importance of virtual reality}

Caruntu and Ditoin (2014) have claimed that all tourist destinations across the world should provide tourists with high quality services regarding the factors of excellence, uniqueness, and creativity to satisfy their needs and desires. In addition, s/he is the main evaluator of the quality of tourism and hospitality services. It is not based on the service's outcomes only, but depends on a long series of actions and performance. Nowadays, 
searching for tourist attractions with its temptations and extensive hotel capabilities is an easy process, especially under the intense competition among hospitality and tourism factors. Hence, virtual reality is an important issue that was raised as it creates a real environment to experience reality. It is a strong competitive advantage of the tourist attraction, including the services that decrease its intangibility and motivates tourists to travel. Liu et al. (2015) illustrated that the real and effective competitive advantage is to provide the guest with all aspects of the service. It is more effective in the service and its aspects, and creating confidence between the service and consumer through real-life examples before the real consumption to test the quality, genius, and uniqueness of services. It also gives a real mental image, even if this requires money and effort, if any. Currently, this concept has not been limited to computer techniques, but it has extended to emerge several life aspects to allow distant interaction and eliminating space, time, and persons. It is possible to experience reality whatever the conditions are. Additionally, its function is embedded in its vitality and is based on transferring feeling and senses (Akhmeto et al., 2015).

\section{Advantages of applying virtual reality}

1- Savings the expenses of establishing real systems.

2- Simulating the systems that the conditions impose existence inside them to be really created (buildings/cars/planes)

3- Experiencing the systems that are difficult to exist inside or near and utilizing interaction with; to maximize the opportunities of understanding performing their functions (Guttentag,2010).

4- It is a mean that can be used to live an imaginary and real experience with our physical senses (sight, hearing, and touching). It does not require using imaginary capabilities. It makes the human, even in childhood, able to see what the designer want to communicate in the desired strength and effect as the next picture shows ( Elshereef,Pantelidis,2010).

Figure 1: using virtual reality in discovering far environments easily

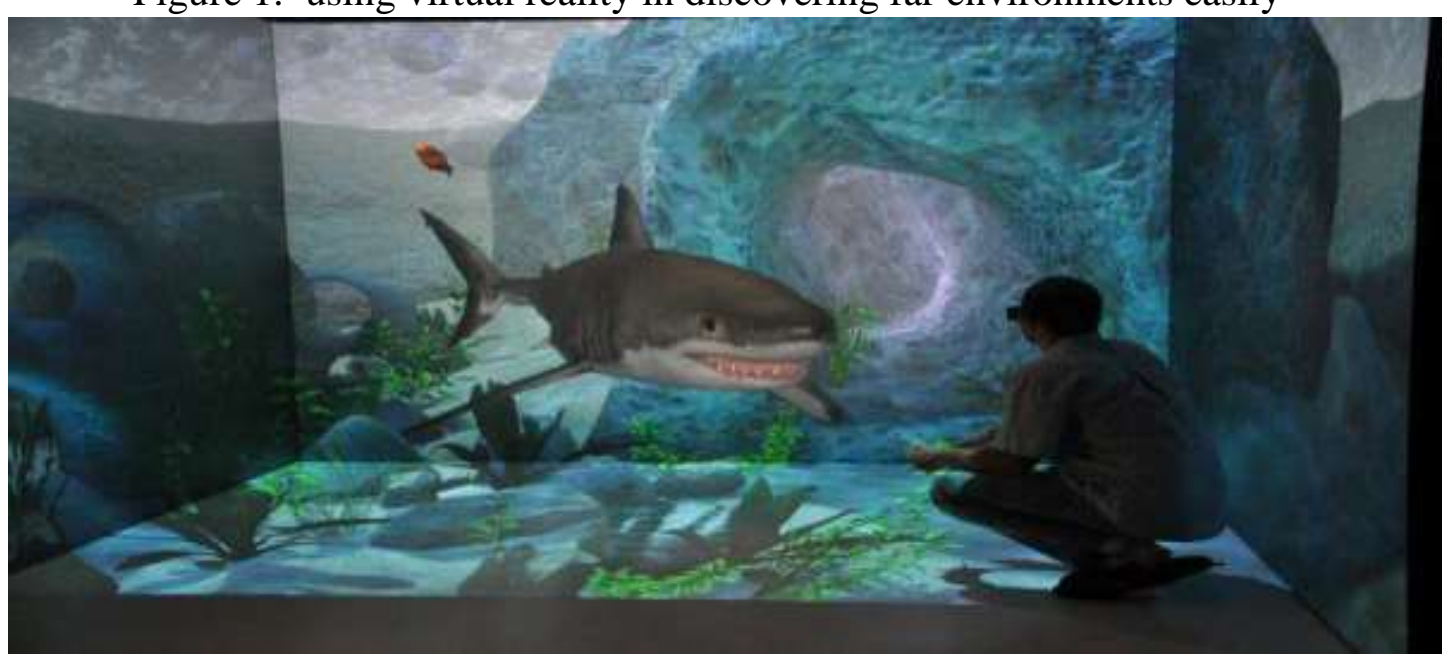

Source (Keyser, 2012). 


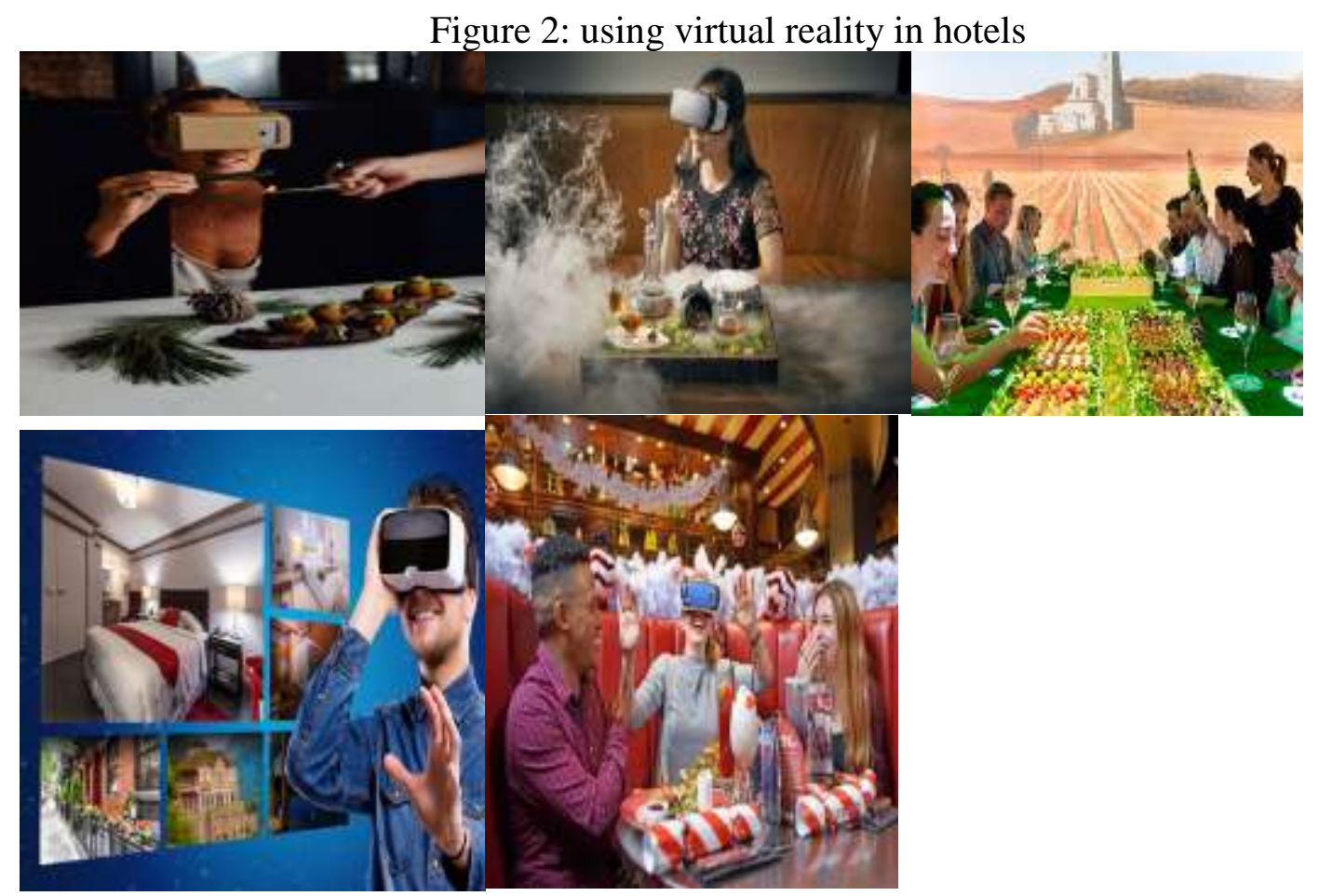

Source (Tromp ,2017)

Applications of virtual and augmented realities in some fields of tourism and hotels

1. On November $17^{\text {th }}, 2016$, Dubai launched a promotional campaign Which was called "Dubai 360". Tourism Festival succeeded in applying virtual reality in Waterloo station in London to introduce its touristic attractions using developed techniques that enable people to enjoy senses, sounds, and attractions. The visitors were invited to contact with "Visit Dubai" and its partners, including IMG World of Adventure and it is the largest entertainmental city in the world and Dubai Parks and Resorts. A platform was designed to contact with the workers at in touristic sector, more than (50) partners.It was an ideal platform called Dubai for tourism, as it was considered as international trade show and it was a good opportunity to the partners to interact with the media and tourism specialists and make deals to attract more visitors from the United Kingdom in the near future in London .

2. "Beyond The Map" project was launched by Google's cultural initiative to introduce Rio de Janeiro in Brazil using interactive $360^{\circ}$ videos via watching tools, e.g. (VR headset) as well as augmented reality via the links and details from interactive texts. Some videos in the Olympiad of Brazil were taken by $360^{\circ}$ technology. By integrating the augmented reality, an interactive explanation of the various places could be found. A person could also move from a place to another in the city

3. In November 2015, the investigative journal "Frontier" published an experiment of $360^{\circ}$ technology that allows viewers identify to Ebola and its outbreak. A person could change the angels of watching the video to broaden the image to display more information. It was produced by The New York Times

4. "SKY ride" that takes the tourist in a terrific round of New York is another interactive experience. It adds another feeling to the viewer, i.e. movement. That is, seats do not move, but a person flies. One of the viewer's said that she felt astonished to find herself flying by New York's. Skyscrapers (Alarabiya,2016) 


\section{Tools of incorporating virtual reality}

Creating and handling a virtual environment includes many tools, as follows:

\section{A. Tools of creating virtual environment}

Lately, machines have greatly been developed. They form a container that takes a person from reality to the virtual world. They have a certain ability and professional technique of displaying the real environment of tourism and hotels services on one or more screen(s), a helmet, or a glass. They include computers with their software that allow creating 3D models and a real simulation of the environment. In addition, sound software may be added to create the appropriate stereophonic sounds to complete the virtual environment, draw an imaginary image, and sense devices, e.g. gloves that are treated, and prepare the appropriate responses such as fear, excitement, magic, satisfaction, heat, coldness, surrounding environment, and quality. That is, using these devices can consolidate augmented reality, especially in entertainment aspects (Jerlard, 2015). As shown at the following pictures in the next pages.

\section{B. Tools of dealing with virtual reality}

- Visualization

- Displays and projectors

- Head mounted display

Figure 3: HMD devices

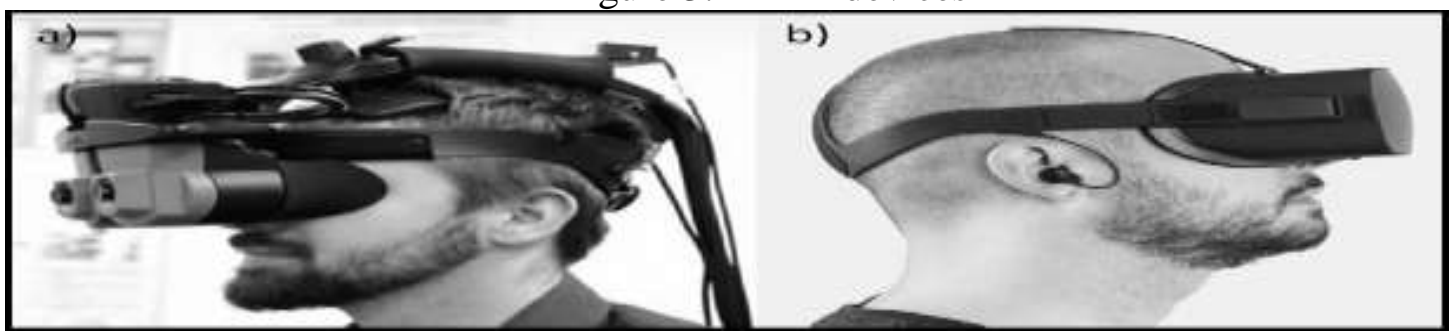

Source (b) Oculus Rift CV119. (Bun et al., 2017).

Some devices are used to create the visual extension and field for the tourists and guests on the displays. They are movable or fixed on the walls to allow them to move. They should fill as much as possible of the visual field (Kysela, J., \& Štorková, 2015).

Figure 4: display devices and 3D glasses

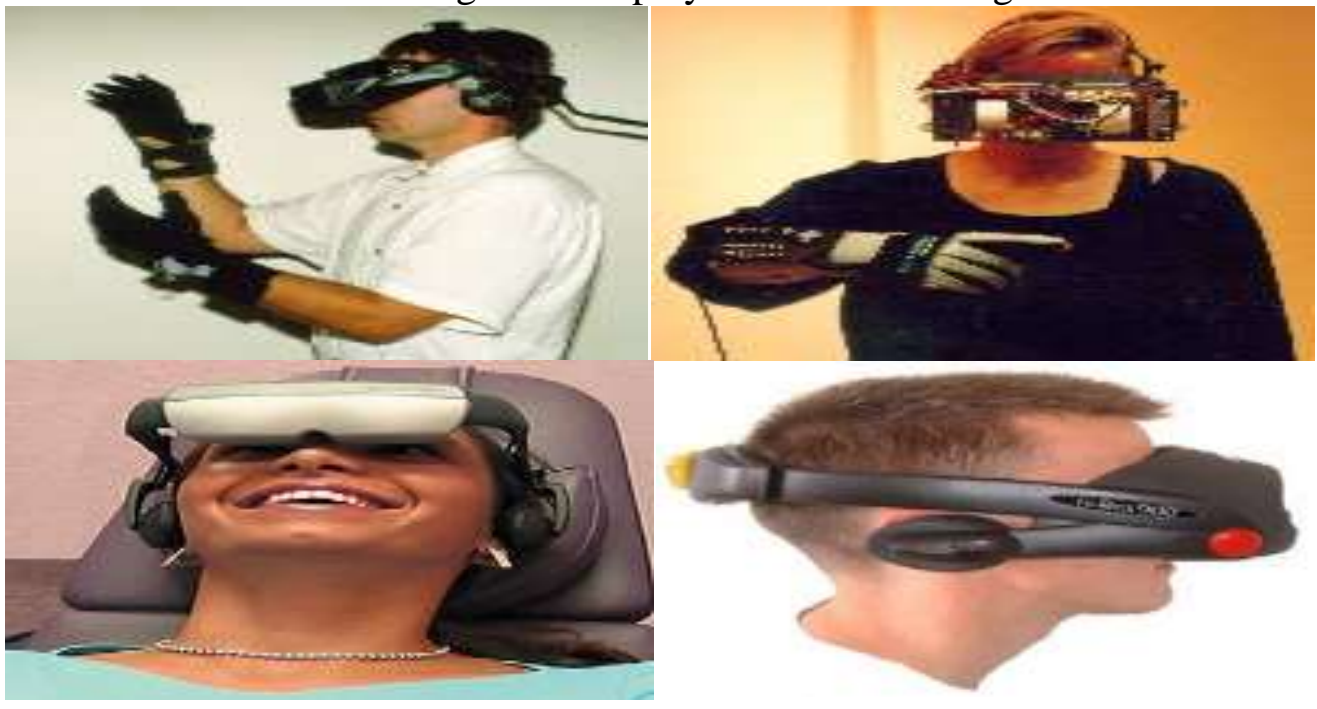

Source (Bellini, 2016). 


\section{D glasses}

- Driven equipment

- Mounted equipment

- Control \& touch

- Grasp

- Position tracking

- 3D sound (Bellini, 2016).

\section{Multi-Display System}

The field of vision in this system of virtual reality is (projectors). It utilizes a more advanced and complicated system, known as (Cave system) designed by the University of Illinois. It uses three display screens (right, forward, and left views) to make the field of view larger. It makes the tourist closer to the real world. It provides immersion by displaying a 3D image of the internal walls of a cube as big as a ball (6 displays). Many persons with or without virtual reality glasses can move into the system to create artificial reality. Augmented reality is a result of the virtual one, especially at tourism and hospitality field. It is the bridge among the computer, display, electronic devices and digital information aswellas reality (Choi, 2016).
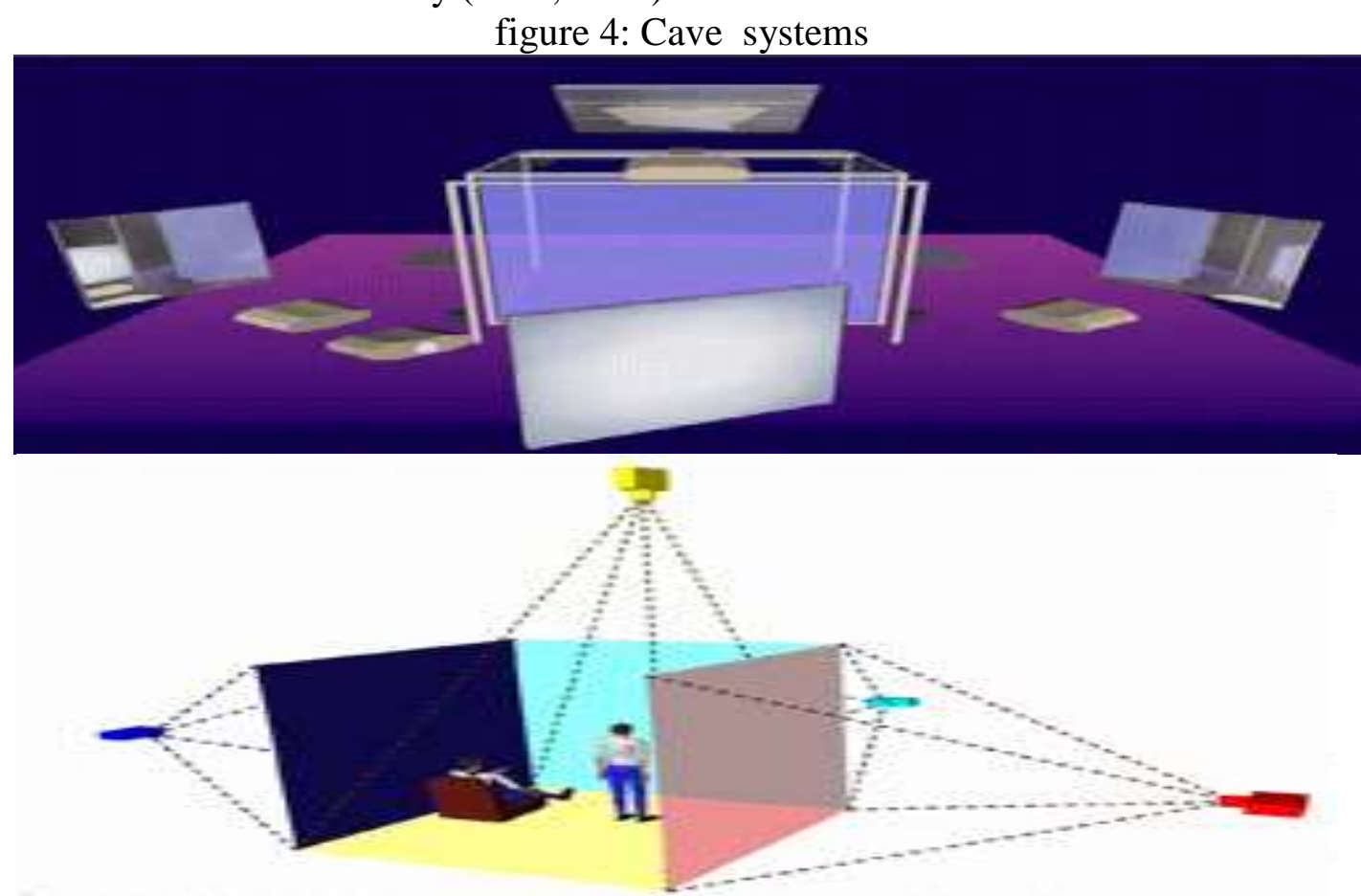

Cave system Elshafey (2012)and Bun et al. (2017)

The tools of fixing grasping and control to coexist the tourism and hotel services

They are the devices that enable the tourist to touch and grasp bodies, devices, plates, and the real surrounding environment, but in a virtual world. For example, gloves allow the movement of the finger to make reactions. 


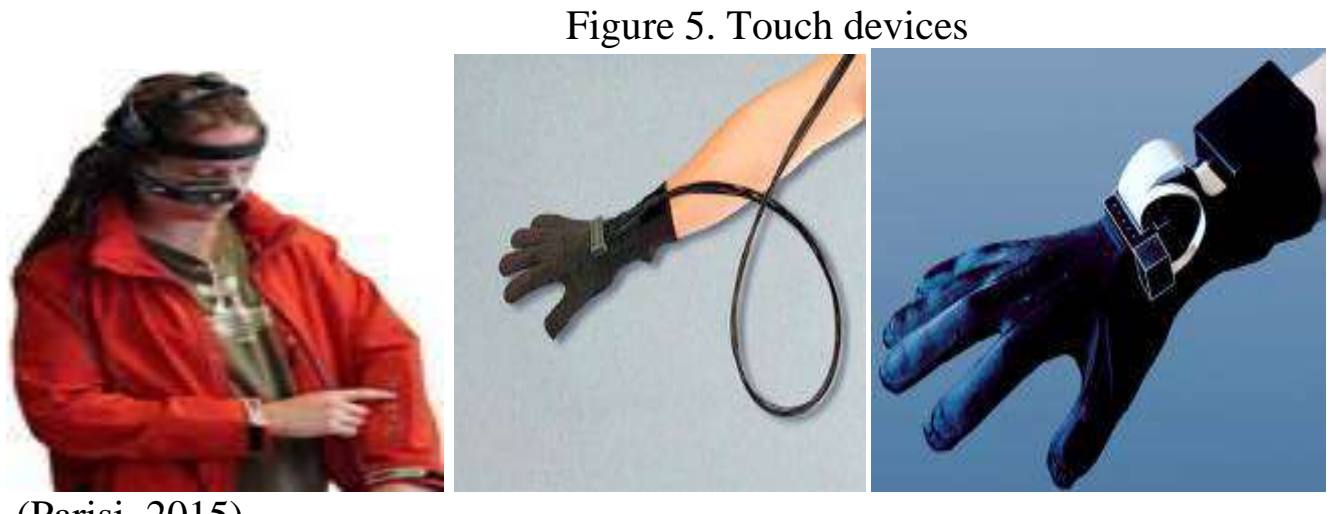

(Parisi, 2015).

\section{D stereo sound}

It is an important element in giving reality to the virtual world. In reality, sounds are threedimensional. For example, the sound of a plane decreases when it moves away. It is also received from all dimensions. The same case is created in virtual reality, e.g. the sounds of waterfalls, noise, surrounding environment, and music in a restaurant. (Zarzuela etal .2013)

\section{Tracking system}

These devices are used to monitor and track the position and direction of the tourist's head and movement of arms using a camera that monitor his/her movement through being affected by his/her presence through position tracking devices as they contain sensitive devices to the movement and position. They work fast and accurately to change the scene on the display when the head moves. In addition, they are equipped with stereo sound devices to make the sound match head movement. For example, if a tourist looks forward, $\mathrm{s} / \mathrm{he}$ sees a swimming pool. If s/he looks right, s/he sees a snack bar. If s/he looks left, s/he finds clothes taking- off rooms, etc. However, virtual reality has some disadvantages. The most significant of which is cost, i.e. cost of application. But if it is compared to marketing fees, the return will be higher (Seidel and Chatelier, 2013).It is largely applied to all fields, including medicine and engineering. It can be used to train on performing and controlling serious surgeries. Thus, it is more accurate to be applied to hospitality and tourism

\section{Hospitality and tourism management in the digital age}

Hospitality and tourism industry clarified that information technology affected the tourist experience positively. Tourism and Hospitality industry has involved the development of modern information technology, including (GRS), (POS) and (GDS) as working systems in the tourism and hotel sector. Thus, the concept of "Prosumers" tourist, who participates in product's development and design, has been enhanced. Cloud computing and smart phones have tremendously increased the services which information technology provides. Accordingly, the relation between service provider and the consumer has been enhanced. Such development not only occurs at tourism and hospitality sector, but also agriculture, medicine, pharmacy, and engineering fields as well. This sector is more affected than other sectors, so it may face much instability (Sezgin, 2016). Fan and Wang (2012) added that virtual reality enhances the awareness and perception of the tourist before travelling. It also makes him/her more aware of the nature of service provided and formerly interacts with its quality. It is a strong feedback process that motivates travelling. 


\section{Study Methodology}

The study depended on the analytical perspective method. The researchers gathered data through designing three questionnaires for the study sample which consisted of the managers of tourism and hospitality services marketing at the hotels sectors, travels agents in Luxor and a random sample of tourists in Luxor. A total of 90questionnaires were distributed to managers of tourism and hospitality services marketing at hotels, tour operators, travel agents; and tourists. Sixty tourists was given 60 questionnaire, only 40 tourists, who reside in Luxor and they were from different nationalities, responded achieving $60 \%$.As for managers, who are managers of tourism and hospitality services marketing ,thirty manager were given a questionnaire for each person, only 24 managers positively shared the interview in Luxor. Ten of them were managers at hotels, and the remaining fourteen manager were tour operators and travel agent. The gathered data was checked, coded, entered into SPSS for analysis.

\section{Results and Discussions}

Table (1) Stability and Reliability Analysis

Table (1): Reliability analysis of the independent variables used in the research

\begin{tabular}{|l|c|c|}
\hline \multicolumn{1}{|c|}{ The Axis } & No. of statements & Alpha Coefficient \\
\hline Establishment Name & 1 & Objective measure \\
\hline Tourist age & 1 & Objective measure \\
\hline Tourist nationality & 1 & Objective measure \\
\hline Educational level & 1 & Objective measure \\
\hline $\begin{array}{l}\text { Services marketed using virtual reality } \\
\text { techniques }\end{array}$ & 5 & 0.6 \\
\hline Importance of virtual reality techniques & 5 & 0,9 \\
\hline Tourist satisfaction & 9 & 0.9 \\
\hline $\begin{array}{l}\text { Challenges of applying virtual reality } \\
\text { techniques }\end{array}$ & 6 & 0,76 \\
\hline
\end{tabular}

Alpha Coefficient is a model of internal consistency, based on the average inter-item correlation. As mentioned at the previous table, Alpha Coefficient for all variables was above the minimum acceptable level of 0.60 suggested by Hair et al., (1998), so that the study measurements were acceptable and reliable.

\section{Response Rate}

The study tool was applied on (90) tourist and manager of hotels, tour operators and travel agents. All targeted tourists and managers were contacted. .However, as for tourists, (40) tourist of sixty tourists responded to the questionnaire, achieving a response rate of (66. $\%$ ), on the other hand, (30) managers were investigated, only (24) of them responded, with a response rate of $(80 \%)$

Table 2: Sample characteristics

\begin{tabular}{|l|l|l|l|}
\hline Variable & & No. & Percentage \\
\hline Establishment Type & Hotels & 10 & $42 \%$ \\
\cline { 2 - 4 } & Tour operators/ travel agent & 14 & $58 \%$ \\
\hline \multirow{5}{*}{ Tourist age } & $15-30$ & 10 & $25 \%$ \\
\cline { 2 - 4 } & $31-50$ & 11 & $27.5 \%$ \\
\cline { 2 - 4 } & $51-70$ & 16 & $40 \%$ \\
\cline { 2 - 4 } & Up- 70 & 3 & $7.5 \%$ \\
\hline \multirow{2}{*}{ Nationality } & Arab & 12 & $30 \%$ \\
\cline { 2 - 4 } & Australia & 3 & $7.5 \%$ \\
\hline
\end{tabular}




\begin{tabular}{|l|l|l|l|}
\hline \multirow{5}{*}{} & Canada & 1 & $2.5 \%$ \\
\cline { 2 - 4 } & England & 3 & $7.5 \%$ \\
\cline { 2 - 4 } & France & 1 & $2.5 \%$ \\
\cline { 2 - 4 } & Germany & 3 & $7.5 \%$ \\
\cline { 2 - 4 } & Irish & 1 & $2.5 \%$ \\
\cline { 2 - 4 } & New Zealand & 3 & $2.5 \%$ \\
\cline { 2 - 4 } & Spain & 1 & $2.5 \%$ \\
\cline { 2 - 4 } & USA & 11 & $27.5 \%$ \\
\cline { 2 - 4 } & Venezuela & 1 & $2.5 \%$ \\
\hline \multirow{5}{*}{ Educational Level } & Male & 18 & $45 \%$ \\
\cline { 2 - 4 } & Female & 22 & $55 \%$ \\
\cline { 2 - 4 } & High studies & 23 & $57 \%$ \\
\cline { 2 - 4 } & Higher education & 6 & $15 \%$ \\
\cline { 2 - 4 } & Intermediate & 6 & $15 \%$ \\
\cline { 2 - 4 } & Under graduate & 5 & $125 \%$ \\
\hline
\end{tabular}

Table (2)shows that the study sample include managers of hotels ,tour operators, travel agent and a random sample of tourists from different countries the number of managers at hotel was(10), seven of them work at (5-star)hotels and the other three work at (4-star) hotels, and whose response was with a percentage of (42\%).In addition, the number of tour operators and travel agent was (14) representing $(58 \%)$ of the population of managers. The sample also included (60) tourists from whom (40) valid questionnaires were obtained. They were aged, as follows: (those whose ages ranged from 51- to70) were ranked first at a percentage $(40 \%)$, while those whose ages were up-70 were ranked the least at a percentage (8.7\%). In addition, (those whose ages ranged from 31to 51) achieved (27.5\%) .While the Arabs were ranked first at a percentage (31\%), the Americans were ranked second at a percentage $(27.5 \%)$ and the Germans, Australians, and New Zealanders were ranked third with a percentage $(7.5 \%)$ for each. The English, New Zealanders, and others achieved $(2.5 \%)$. Males were $(45 \%)$ while females were $(55 \%)$. Master holders were ranked first at a percentage $(57.5 \%)$, while those with higher and intermediate diploma were ranked second with a percentage $(15 \%)$ for each, and under graduate were ranked the last at a percentage $(12.5 \%)$.

Table 3: Descriptive Statistics of Hotel and tourist company questionnaire

\begin{tabular}{|c|c|c|c|c|}
\hline \multirow{3}{*}{$\begin{array}{c}\text { Variable } \\
\text { Establishment type }\end{array}$} & & & No. & Percentage \\
\hline & \multicolumn{2}{|c|}{ Hotels } & 10 & $42 \%$ \\
\hline & \multicolumn{2}{|c|}{$\begin{array}{l}\text { Tour operators/ travel } \\
\text { agent }\end{array}$} & 14 & $58 \%$ \\
\hline \multirow{4}{*}{$\begin{array}{l}\text { virtual reality techniques } \\
\text { application }\end{array}$} & \multirow[t]{2}{*}{ Yes } & Hotels & 8 & $33 \%$ \\
\hline & & $\begin{array}{l}\text { Tour } \\
\text { operators }\end{array}$ & 11 & $46 \%$ \\
\hline & \multirow[t]{2}{*}{ No } & Hotels & 2 & $8 \%$ \\
\hline & & $\begin{array}{l}\text { Tour } \\
\text { operators }\end{array}$ & 3 & $13 \%$ \\
\hline \multirow{4}{*}{$\begin{array}{l}\text { services marketed using } \\
\text { virtual reality techniques } \\
\text { at hotels }\end{array}$} & \multicolumn{2}{|c|}{ Food and beverage } & $7 / 8$ & $87.5 \%$ \\
\hline & \multicolumn{2}{|c|}{ Room cleaning } & $7 / 8$ & $87.5 \%$ \\
\hline & \multicolumn{2}{|c|}{ Furniture quality } & $2 / 8$ & $25 \%$ \\
\hline & \multicolumn{2}{|c|}{ After sale services } & $4 / 8$ & $50 \%$ \\
\hline $\begin{array}{l}\text { services marketed using } \\
\text { virtual reality techniques }\end{array}$ & \multicolumn{2}{|c|}{$\begin{array}{l}\text { Transportation } \\
\text { services }\end{array}$} & $3 / 11$ & $27 \%$ \\
\hline
\end{tabular}




\begin{tabular}{|l|l|c|c|}
\hline \multirow{4}{*}{ at tour operators } & Tourist program & $8 / 11$ & $73 \%$ \\
\cline { 2 - 4 } & Diving tourism & $5 / 11$ & $45 \%$ \\
\cline { 2 - 4 } & Simulation tourism & 0 & 0 \\
\cline { 2 - 4 } & After sale services & $1 / 11$ & $9 \%$ \\
\hline \multirow{4}{*}{$\begin{array}{l}\text { Applying date of virtual } \\
\text { reality technique }\end{array}$} & Less than 6 months & 1 & $4 \%$ \\
\cline { 2 - 4 } & From 6 to 12 months & 5 & $20 \%$ \\
\cline { 2 - 4 } & From1 to 5 years & 3 & $12 \%$ \\
\cline { 2 - 4 } & More than 5 years & 10 & $40 \%$ \\
\hline \multirow{3}{*}{ virtual reality tools } & Glasses & $5 / 19$ & $26.3 \%$ \\
\cline { 2 - 4 } & Projector/monitor & $3 / 19$ & $15.7 \%$ \\
\cline { 2 - 4 } & Touch tools & $16 / 19$ & $84 \%$ \\
\hline
\end{tabular}

Table (3) showed that the hotels that applied virtual reality represent a percentage of (33\%), and Tour operators and travel agents that applied virtual reality fulfilled a percentage $(46 \%)$. However, the hotels that did not apply this technique achieved (8\%), while Tour operators and travel agents that did not apply it achieved (13\%). The most important hotel departments that applied the technique were food and beverage, furniture quality, and after sale services. Only transportation services and tourist program departments applied it at tour operators and travel agents. Thus, it is clear from the analysis that the questionnaire results of the managers of hotels, tour operators, and travel agents disagree with the results of tourists questionnaires. Hence, the managers asserted applying virtual reality technique, while the tourists argued that it was not applied to promote tourism and hospitality services. This is the essence of the study's problem. It represents an extreme shortage of promoting tourism and hospitality services, i.e. transferring a real and objectifying image of such services causing the increase of motivation, excitement, and experience and eliminating the intangibility and the spatial and temporal aspects, as shown in the former table. This also disagree with what was reported by Akhmeto et al. (2015) that the history of applying virtual reality by hotels, tour operators, and travel agents was ranked first more than five years ago and achieved (40\%). This indicates the unreal responses of the managers of hotels, tour operators, and travel agents as it was not applied yet in the field in Egypt. Now, it is possible to introduce this technique as a part of the educational field. In addition, its discussion and application at the field only received attention in 2013. This agrees with what Warren and Wakefield (2015) and Xia et al. (2013) stated. When investigating virtual reality tools in hotels, tour operators and travel agents, the table shows that touch tools were ranked first (84\%), while glasses were ranked second $(26.3 \%)$ and projectors were ranked third $(18.7 \%)$. This reflects the confusion between the reality of virtual reality technique as a separate tool and some tools of emarketing. It may be believed by the managers of hotels, tour operators, and travel agents that they are touch tools, e.g. using projectors/monitors because its most significant tools are:

- Driven Equipment

- Mounted Equipment

- Control \&Touch

- Grasp

- Tracking Position -3D Sound (Bun et al., 2017).

Table 4: Descriptive Statistics of tourist questionnaire

\begin{tabular}{|l|l|c|c|}
\hline \multirow{2}{*}{ Using virtual reality techniques } & Yes & 9 & $22.5 \%$ \\
\cline { 2 - 4 } & No & 31 & $77.5 \%$ \\
\hline Tourist destination & Turkey & $1 / 9$ & $11 \%$ \\
\hline
\end{tabular}


International Journal of Heritage, Tourism and Hospitality Vol. (11), No. (2/2), September, 2017

By: Faculty of Tourism and Hotels, Fayoum University

\begin{tabular}{|l|l|l|c|}
\hline \multirow{2}{*}{ virtual reality tools } & Lebanon & $2 / 9$ & $22 \%$ \\
\cline { 2 - 4 } & Other & $6 / 9$ & $66.6 \%$ \\
\cline { 2 - 4 } & Glasses & $5 / 9$ & $55.5 \%$ \\
\cline { 2 - 4 } & Projector/monitor & $6 / 9$ & $66.6 \%$ \\
\cline { 2 - 4 } & Touch tools & $4 / 9$ & $44.4 \%$ \\
\hline
\end{tabular}

The table shows the tourists who used this technology represented a percentage $(22.5 \%)$, while those who did not use it represented a percentage $(77.5 \%)$ ).Turkey and Lebanon were the leading countries in the field as they were visited according to virtual reality technique. Tourists mainly used glasses, monitors, and touch tools. This shows an extreme contradiction between the analysis of tourists' results and the results of the managers of hotels, tour operators and travel agents. All tourists did not use this technique in Egypt and tourism and hospitality services were not marketed abroad although the managers of hotels, tour operators, and travel agents asserted the application of virtual reality in tourism services. Accordingly, the problem of the study is defined through the real contradiction between the understanding and application of virtual reality by the managers of hotels, tour operators, and travel agents that may reach the inapplicability and total comprehension of its concept. It depends on the simple methods of e-marketing. That is, e-marketing tools and virtual reality with its equipment and tools are confused. This proves the first hypothesis of the study. Thus, it contradicts with what was stated at the studies of Liu et al. (2015) and Sejzi et al. (2012) that illustrate that virtual reality is a comprehensive environment that runs by computer or a software. The user enters and interacts with reality to acquire confidence through the real and correct reflections of the product or service (visual embodiment). Furthermore, virtual reality is a strong tool to evaluate products and services by touching and real embodying.

Table 5: Statistics for the importance of applying virtual reality techniques at hotels, tour operators and travel agent according to mangers of hotels and travel agent

\begin{tabular}{|l|l|l|l|l|}
\hline Items & $\begin{array}{l}\text { Importance of applying virtual reality techniques at } \\
\text { hotels and tour operators }\end{array}$ & $\mathrm{M}$ & $\mathrm{SD}$ & $\mathrm{Sig}$. \\
\hline 1 & Transferring a real and objectifying image of reality & 3.75 & 1.4 & 0.42 \\
\hline 2 & $\begin{array}{l}\text { Effective impact in making purchase decision } \\
\text { Overcoming the intangibility of hotels and tourism } \\
\text { services }\end{array}$ & 3.5 & 1.34 & 0.2 \\
\hline 3 & Highlighting the quality of hotels services & 3.6 & 0.96 & 0.07 \\
\hline 5 & $\begin{array}{l}\text { Illustrating the natural and } \\
\text { archaeological factors of the tourist attractions }\end{array}$ & 3.7 & 1 & 0.38 \\
\hline
\end{tabular}

$\mathrm{M}=$ Mean SD = Standard Deviation Sig.= significance degree of one-sample T-Test

Table (5) indicated that the most effective variable was "1 (Transferring a real and objectifying image of reality) ", whose mean value was (3.75) and standard deviation (1.4). One-sample T-test (with test value (4) that referred to "agree" answer) showed that there was no difference with a statistical significance between respondents' awareness of all variables and the test value $(p=.125)$ where $p$-level was definitely more than .05 ( so the null hypothesis of this variable was accepted). This result reflected that respondents' awareness of most variables exceeded the test value. This result reflected that respondents' awareness of most variables exceeded the test value. The table showed that all the advantages that can be obtained via virtual reality are 
extremely close and integrated. Thus, they should be totally achieved. This agrees with the study of Akhmeto et al. (2015).

Table 6: Statistics for the difficulties and challenges of applying virtual reality techniques at hotels, tour operators and travel agent

\begin{tabular}{|l|l|l|l|l|}
\hline Items & $\begin{array}{l}\text { difficulties and challenges of applying virtual reality } \\
\text { techniques }\end{array}$ & $\mathrm{M}$ & $\mathrm{SD}$ & Sig. \\
\hline 1 & The high cost of the tools of creating virtual reality & 2.8 & 1.3 & .0001 \\
\hline 2 & Guests and customers are reluctant to use virtual reality & 2.6 & 1.3 & 0.014 \\
\hline 3 & The problem of maintaining the equipment of virtual reality & 2.4 & 1.1 & 0.056 \\
\hline 4 & Applying virtual reality requires more time & 2.5 & 1.1 & 0.015 \\
\hline 5 & Virtual reality causes health problems to the customers & 2.6 & 1.4 & 0.015 \\
\hline 6 & Organizational \& administrative obstacles & 2.7 & 1.01 & 0.001 \\
\hline 7 & Legal \& technical obstacles & 2.6 & 0.8 & 0.000 \\
\hline Statistics for all Variables & 2.8 & 1.3 & 0.001 \\
\hline
\end{tabular}

$\mathrm{M}=$ Mean SD = Standard Deviation Sig.= significance degree of one-sample T-Test

Table (6) indicates that. The most effective challenge variable was " 3 ". The problem of maintaining the equipment of virtual reality"whose mean value was (2.4) and standard deviation was (1.1). One sample T-test (with test value (2) that referred to "agree" answer), showed that there were differences with statistical significance between respondents' awareness of all difficulties, The test value $(p=.001)$ where $p$-level was definitely less than .05 ( so the null hypothesis of this variable was rejected).

Table 7: The importance of applying virtual reality techniques at hotels, tour operators and travel agent

\begin{tabular}{|c|c|c|c|c|c|}
\hline Very disagree & disagree & neutral & agree & Very agree & mean \\
\hline 0 & 0 & 1 & 4 & 19 & 4.7 \\
\hline
\end{tabular}

The table (7) shows that the managers of hotels, tour operators, and travel agents agree on the necessity of applying the technology of marketing tourism and hospitality services. However, actual situation shows a gap between persuasion and application. We should follow the model of the touristic tigers that apply modern technology. This agrees with Pan Li-xin (2016) that reported that despite the great development of modern age technology, Egypt suffers from lack in creating tourism and hotel information. It should compete with other countries.

Table 8: The importance of helping of ministry of tourism

\begin{tabular}{|l|l|l|l|l|l|}
\hline Very disagree & disagree & neutral & agree & Very agree & mean \\
\hline 0 & 1 & 6 & 3 & 14 & 4.25 \\
\hline
\end{tabular}

Table (8) shows that the managers of hotels and tour operators agree that technical and motivating support should be provided by Ministry of Tourism. They mainly perceive this support in its various forms. This agrees with the experience of the leading companies in virtual reality application, e.g. UAE and USA. Accordingly, the state should take steps and respond to the vision of World Tourism Organization.

Table (9): Statistics for the tourist satisfaction of applying virtual reality techniques at hotels, tour operators, and travel agents

\begin{tabular}{|c|l|c|c|c|}
\hline Items & Advantage of applying virtual reality & M & SD & Sig. \\
\hline 1 & Transferring a real and objectifying image of reality & 3.5 & 1.3 & 0.347 \\
\hline 2 & Effective impact in making purchase decision & 3.5 & 0.8 & 0,169 \\
\hline
\end{tabular}


International Journal of Heritage, Tourism and Hospitality Vol. (11), No. (2/2), September, 2017 By: Faculty of Tourism and Hotels, Fayoum University

\begin{tabular}{|c|l|c|c|c|}
\hline 3 & Overcoming the intangibility of tourism services & 3.8 & 1.7 & 0.78 \\
\hline 4 & $\begin{array}{l}\text { Highlighting the quality of tourism and hospitality } \\
\text { services }\end{array}$ & 4.2 & 0.66 & 0.35 \\
\hline 5 & $\begin{array}{l}\text { Illustrating the natural and } \\
\text { archaeological factors of the tourist attractions }\end{array}$ & 4 & 1 & 1 \\
\hline 6 & Further explanation of the tourist program items & 3.8 & 0.78 & 0.68 \\
\hline 7 & Highlighting the quality of food and beverage & 3.4 & 1.2 & 0.24 \\
\hline 8 & $\begin{array}{l}\text { Highlighting the ability and efficiency of the staff in } \\
\text { problem solving }\end{array}$ & 3.5 & 1.3 & 4.3 \\
\hline 9 & Showing room cleanness and furniture quality & 3.4 & 1.2 & 0.21 \\
\hline Statistics for all variables & 3.7 & 0,82 & 0.35 \\
\hline
\end{tabular}

M = Mean SD = Standard Deviation Sig. = significance degree of one-sample T-Test

Table (9) indicated that the most effective variable was "highlights the quality of tourism and hospitality services "whose the mean value was (4.2) and standard deviation value was (0.66). One-sample T-test (with test value (4)) showed that there was no difference with a statistical significance between respondents' awareness of all variables and the test value $(\mathrm{p}=.35$ ) where $\mathrm{p}$-level was definitely more than .05 ( so the null hypothesis of this variable was accepted. All the previously mentioned factors were extremely significant and integrated that reflect the importance of applying this technology at the field of tourism and hospitality industry. The importance of disseminating their application in the field is maximized. This agrees with the study of Liu et al. (2015). To test the validity of first hypothesis of the research. Independent samples t-test was used, as follow:

Table (10): The importance of applying virtual reality techniques to hotels, tour operators, and travel agents

\begin{tabular}{|l|l|l|l|l|l|}
\hline Very disagree & disagree & neutral & agree & Very agree & mean \\
\hline 0 & 1 & 1 & 4 & 19 & 4.7 \\
\hline
\end{tabular}

The table (10) shows that the managers of hotels, tour operators, and travel agents agree on the necessity of applying the technology of marketing tourism and hospitality services. However, reality shows a gap between persuasion and application. We should follow the model of the tourist tigers that apply modern technology. This agrees with the study of Pan Li-xin (2016) that reported that despite the great development of modern age technology, Egypt is late in creating tourism and hotel information. It should compete with other countries.

Table 11: the importance of helping the Ministry of Tourism for hotels and travel agent in applying virtual reality technique

\begin{tabular}{|l|l|l|l|l|l|}
\hline Very disagree & disagree & neutral & agree & Very agree & mean \\
\hline 0 & 0 & 6 & 3 & 14 & 4.25 \\
\hline
\end{tabular}

Table (11) shows that the managers of hotels and tour operators agree that technical and motivating support should be provided by Ministry of Tourism. They mainly perceive this support in its various forms. This agrees with the experience of the leading companies in virtual reality application, e.g. UAE and USA. Accordingly, the state should take steps and respond to the vision of World Tourism organization

Table 12: Statistics for the tourists' opinion about the difficulties and challenges of applying virtual reality techniques at hotels and tour operators

\begin{tabular}{|c|l|l|l|l|}
\hline Items & & $\mathrm{M}$ & $\mathrm{SD}$ & Sig. \\
\hline 1 & Transferring a real and objectifying image of reality & 2.8 & 1.3 & 0.000 \\
\hline 2 & Effective impact in making purchase decision & 2.6 & 1.3 & 0.000 \\
\hline 3 & Effective impact in making purchase decision & 2.4 & 1.17 & 0.000 \\
\hline
\end{tabular}




\begin{tabular}{|c|l|c|c|c|}
\hline 4 & Overcoming the intangibility of tourism services & 2.5 & 1.17 & 0.000 \\
\hline 5 & $\begin{array}{l}\text { Illustrating the natural and } \\
\text { archaeological factors of the tourist attractions }\end{array}$ & 2.6 & 1.46 & 0.000 \\
\hline 6 & $\begin{array}{l}\text { Highlighting the ability and efficiency of the staff in } \\
\text { problem solving }\end{array}$ & 2.7 & 1 & 0.000 \\
\hline \multicolumn{2}{|l|}{ Statistics forall variables } & 2.6 & 0.874 & 0.000 \\
\hline
\end{tabular}

$\mathrm{M}=$ Mean SD = Standard Deviation Sig. = significance degree of one-sample T-Test

Table (12) indicated that the most effective challenge was " 3"( Effective impact in making purchase decision) "whose mean value was (2.4) and standard deviation (1.17). One sample T-test (with test value (value (2) that refered to "agree" answer) occurred that there was a statistical significant differences between respondents' awareness of all variables and the test value $(\mathrm{p}=0.000)$ where $\mathrm{p}$-level was definitely less than .05 ( so the null hypothesis of this variable was rejected).

Table 13: Differences between hotels, tour operators and travel agent in application of virtual reality techniques

\begin{tabular}{|l|c|c|c|}
\hline \multicolumn{1}{|c|}{ The Axis } & $\mathrm{N}$ & Mean & Sig. \\
\hline Applying at hotels & 8 & 1.2 & 0.872 \\
Applying at tour operators & 11 & 1.21 & \\
\hline
\end{tabular}

According to table (13), the significance level was more than 0.05 (0. 872), this meant that There is no significantly differences between hotels and tour operators in application of virtual reality techniques. These results coincided that the first hypothesis of the study was correct One-Sample T-test (with test value (4)) was used to test the second hypotheses of the research as follow:

Table 14: One-Sample T-test between tourist satisfaction of virtual reality techniques at hotels and tour operators and tourist satisfaction standard

\begin{tabular}{|lc|l|}
\hline Variable & health affairs standards \\
\hline tourist satisfaction of & Mean & 3.7 \\
virtual reality techniques & Sig. (2-tailed) & 0.355 \\
& No. & 9 \\
\hline
\end{tabular}

To apply one-sample T-test, the value (14) was suggested because it was a suitable value that referred to tourists approval status of virtual reality techniques applied at hotels and tour operators. The results showed that the p-value were definitely more than .05 ( 0.355$)$. So, the null hypothesis was acceptable and the second hypotheses of the research were valid. In the other word, there are no differences with a statistical significance between tourist satisfaction of virtual reality techniques at hotels and tour operators and tourist satisfaction standard. To test the validity of third hypothesis of the research, the relationship between the educational qualification of tourists and the use of virtual reality techniques was tested; a spearman's correlation coefficient with significance level 0.05 was calculated for this relationship.

Table 15: Correlation coefficiency between the educational qualification of tourists and the use of virtual reality techniques

\begin{tabular}{|ll|l|}
\hline Variable & educational qualification \\
\hline the use of virtual & Spearman Correlation & 0.05 \\
reality techniques & Sig. (2-tailed) & 0.72 \\
& No. & 40 \\
\hline
\end{tabular}

According to table (15) the significance level was more than $0.05(0.72)$ and spearman's correlation coefficient was 0.05 , this meant that there was no a statistical significant correlation between the educational qualification of tourists and their use of virtual reality techniques. These results coincided that the third hypothesis of the study was correct. To test the validity of fourth hypothesis of the research, the relationship between the tourist 
age and the use of virtual reality techniques was tested; a spearman's correlation coefficient with significance level 0.05 was calculated for this relationship.

Table16: Correlation coefficient between the tourist age and the use of virtual reality techniques

\begin{tabular}{|lc|l|}
\hline Variable & tourist age \\
\hline the use of virtual & Spearman Correlation & 0.159 \\
reality techniques & Sig. (2-tailed) & 0.328 \\
& No. & 40 \\
\hline
\end{tabular}

According to table (16), the significance level was more than $0.05(0.328)$ and spearman's correlation coefficient was 0.159 , this meant that there was no a statistical significant correlation between the tourist age and their use of virtual reality techniques. These results coincided that the fourth hypothesis of the study was correct. To test the validity of fifth hypothesis of the research, the relationship between the educational qualification of tourists and the level of their satisfaction of virtual reality techniques was tested; a spearman's correlation coefficient with significance level 0.05 was calculated for this relationship.

Table 17: Correlation coefficiency between the educational qualification of tourists and the use of virtual reality techniques

\begin{tabular}{|ll|l|}
\hline Variable & Educational qualification \\
\hline Tourist satisfaction & Spearman Correlation & 0.145 \\
& Sig. (2-tailed) & 0.71 \\
& No. & 40 \\
\hline
\end{tabular}

According to table (17), the significance level was more than $0.05(0.71)$ and spearman's correlation coefficient was 0.05 , this meant that there was no a statistical significant correlation between the educational qualification of tourists and level of their satisfaction of virtual reality techniques. These results coincided that the fifth hypothesis of the study was correct.

Table 18: level of tourist's satisfaction of virtual reality techniques with $95 \%$ confidence interval for percentage at hotels and tour operators

\begin{tabular}{|l|c|c|c|}
\hline \multicolumn{1}{|c|}{ The Axis } & Mean of percentage & $\begin{array}{c}95 \% \text { Confidence Interval } \\
\text { for percentage }\end{array}$ & Attitude \\
\hline $\begin{array}{l}\text { tourists } \\
\text { satisfaction }\end{array}$ & $77.5 \%$ & $61.8-87 \%$ & $\begin{array}{c}\text { Moderate } \\
\text { level }\end{array}$ \\
\hline
\end{tabular}

95\% Confidence Interval for Mean of the study population $=\bar{X} \mp 1.0025,55 \cdot$ Std.Error From the previous table, it is clear that $95 \%$ confidence interval for percentage of " tourists' satisfaction of virtual reality techniques " was between $61.8 \%$ as a lower bound and $87 \%$ as an upper pound. This meant that tourists' satisfaction of virtual reality techniques has high levels with $95 \%$ confidence interval.

\section{Conclusion}

Virtual reality in tourism and hospitality industry where it can be applied so the tourist can experience and touch reality in another place, especially touristic and hotel services, touristic temptations, touristic transportation services' quality, residence services, and archaeological sites. Egypt suffers from:

1. Lack of full understanding of applying virtual reality by the managers of hotels and tourism companies in promoting their services and confusing it with e-marketing causing the absence of its real application.

2. Shortage of providing virtual reality tools and the comprehensive environment by hotels and tourism companies under tourist depression and limitedness of its using 
because of the high cost of buying the tools and equipment and creating virtual programs.

3. Uncertainty and lack of total understanding of applying virtual reality by the decision makers as they adopt the traditional methods of tourist attractions by tourist companies.

4. Lack of information technology and communication skills, especially in virtual reality environment in tourism and hospitality industry by the staff and graduates of specialized faculties in the computer, information systems, communication technology, and tourism and hotels.

5. Adopting some simple and primitive applications of virtual reality concerning some important archaeological sites that only adopts photos of VR 360 that are available for free for Android system users.

6. Withdrawal of the countries that export tourists and the introduction of countries with massive marketing prices and technologies, e.g. virtual reality in the area.

7. Lack of support of the bodies concerned with tourism and hotel fields, i.e. Ministry of Tourism, whether it is technical, financial, facilitating, or motivating support.

\section{Recommendations}

1. There is urgent need for collaboration and Interest in applying virtual reality at the field of tourism and hospitality because it is one of the greatest outcomes of the technological revolution in the modern age. It creates a real environment where the tourist experience hotel and tourism services and archaeological sites. It creates a kind of excitement, and it eradicates the intangibility of services. It also makes a prior excellent mental image. Additionally, it is attractive in marketing and promoting the tourism and hotel product in terms of the vision of World Tourism Organization 2017 of creating creativity and excellence in promoting tourism and hotel services.

2. Cooperation should be made between the field of hotels and tourism represented by Ministry of Tourism besides other ministries and authorities, e.g. Ministries of Communication, environment, and investment because of the human and technical facilities they have to apply the geographic information (GIS system).

3. Ministry of Tourism should be interested in applying this technique to promote the Egyptian tourism market abroad. The private sector, whether hotels or tourism companies, should also be interested in integrating their marketing cost in the budget of the Ministry and creating huge campaigns by applying the most modern techniques.

4. A training center supervised by the Ministry of Tourism should be established to train the staff of tourism and hotels field on how to update the virtual programs of hotels and tourism companies.

5. Virtual reality should be maximized and circulated as it is fertile in all fields, especially in the military, cinema, sports, labs and innovations, fashion design, and tourism and housing industry, in particular.

6. The Center of Information should provide the type of equipment and tools, design, regular maintenance, and enhancing virtual programs. There should also be a main center of control in case of temporary or sudden failures.

7. Hotels and travel agent should prepare end extremely enhance their products and facilities provided to the tourist, i.e. achieving the highest degrees of appearance and content. For example, programs may be made in food and beverage services, kitchen, restaurant, bars, special restaurants; equipment (room service sector and 
services of tourism companies); and tourist transportation, vehicle's' quality, tourist program, and after sale services.

8. Managers of hotels and travel agent should perceive the importance and the role of technology in tourism and hospitality industry as investment in them is not a waste of time and money but it creates a competitive advantage of the Egyptian touristic and hotel product, especially in the light of the total and fierce competition among countries. They shall also acquire the experience of the leading countries in the field, e.g. UAE and USA.

\section{References}

Alarabiya,(2016). https://www.alarabiya.net/livestream.html.accessed 21/11/2017.

Akhmetov .1. , Faizrakhmanov.M. and Faizrakhmanova.A. , (2015), Virtual Reality in Professional Activity of a Teacher of Technology, Procedia - Social and Behavioral Sciences 191 ( 2015 ) P.2812,2816 -

BLEŠIĆ, I., Ivkov-Džigurski, A., Stankov, U., STAMENKOVIĆ, I., \& Bradić, M. (2011). Research of expected and perceived service quality in hotel management. Revista de turism-studii si cercetari in turism, (11),P 6 ..

Bun, P., Gorski, F., Grajewski, D., Wichniarek, R., \& Zawadzki, P. (2017). Low-Cost Devices Used in Virtual Reality Exposure Therapy. Procedia Computer Science, 104, 445-451 .

Caruntu .A. and Ditoin .M. (2014) .The Perceptions of hospitality Services of a Tourism Destination, -Procedia , Social and Behavioral Sciences ,109 ( 2014 ) 231 - 235, P. 230

El-sayed El-Shafae, Nashwa (2012). Designing clothes between the virtual reality and the digital marketing, the the $7^{\text {th }}$ arab annual conference - the fourth international, knowledge and human capital management at higher education institutions in Egypt and Arab world,11-12 April, faculty of education ,El---Mansoura university, pp. 1399,1397.

El-shrief Louay .(2012). The Virtual Reality and the Practicability at the Palstenian Construction Environment : A Case Study to Overcome the Transferring Problems Cross - Mobility in Naplis City, el-Najah national university,pp.12,15.

Guttentag, D. A. (2010). Virtual reality: Applications and implications for tourism. Tourism Management, 31(5), p.p637-638.

Hair, J. F., Black, W. C., Babin, B. J., Anderson, R. E., \& Tatham, R. L. (1998). Multivariate data analysis (Vol. 5, No. 3, pp. 207-219). Upper Saddle River, NJ: Prentice hall.p.7

Kesselman M.(2016) Current CITE-ings from the popular and trade - computing literature: Google Cardboard - virtualreality for everyone -Library Hi Tech News, Vol. 33 Iss 4 pp. 15 - 16.P.15. Emerald Group Publishing Limited, 0741-9058, DOI 10.1108/LHTN-04-2016-0020 15.

Kesyer. H., (2012), Virtual Reality Teechnology Comes of Age, .com / available at Http: www.telepresenceoptions, // -2012-3-30 image /EON-ICUBE .JPg. P.21.

Kysela, J., \& Štorková, P. (2015). Using augmented reality as a medium for teaching history and tourism. Procedia-Social and behavioral sciences, 174, 926-931.

Lavell .S . (2017), Virtual Reality, press Cambridge University, P.3.

Liu et al. (2015) . The Process Simulation Using by Virtual Reality , 24th DAAAM International Symposium on Intelligent Manufacturing and Automation, Procedia Engineering 69 ( 2014 ) $1015-1020$. 
Sejzi .A., Arise.B., Yahya .N.,(2012), The Phenomenon of Virtual University in New Age: Trends and Changes, International Conference on Teaching and Learning in Higher Education (ICTLHE 2012) in conjunction with RCEE \& RHED 2012 ,Procedia - Social and Behavioral Sciences 56 ( 2012 ) 565 - 572,P.566 .

Tromp.P.,(2017),How Virtual Reality Will Revolutionize the Hospitality Industry. https://www.hospitalitynet.org/opinion/4080737.html.accessed. 15/2/2017.

Tůma .Z. , Tůma.R., Knoflíček .R., Blecha.P., Bradáč.F ,(2014) DAAAM Process Simulation using by Virtual Reality, $24^{\text {th }}$ DAAAM, The International Symposium on Intelligent Manufacturing and Automation, 2013, Procedia Engineering 69 ( 2014 ) 1015 - 1020,1015- ,P.1016 .

Warren .S. and Wakefield.J. (2015), Instructional DesignFrameworks for Second Life ${ }^{\circledR}$ Virtual Learning" In Transforming Virtual World Learning. Published online: 08 Mar 2015; 113-161. P.114. by Emerald Group Publishing Limited.All rights of reproduction in any form reserved .ISSN: 2044-9968/doi:10.1108/S20449968(2011)0000004010 .

WTO,(2017),Http://www.UNWTO.org.acessed 19/1/2017.

Xia.p., Lope.A. and Restivo .M.,(2013), A review of virtual reality and haptics for product assembly (part 1): rigid parts, AssemblyAutomation, Vol. 33 Iss 1 pp. 68 77,p.68. Emerald Group Publishing Limited [ISSN 0144-5154 avilable at www.emeraldinsight.com/0144-5154.htm ..

Zarzuela, M. M., Pernas, F. J. D., Calzón, S. M., Ortega, D. G., \& Rodríguez, M. A. (2013). Educational tourism through a virtual reality platform. Procedia Computer Science, 25, 382-388.

Zein el-din muhammmad Mahmoud.(2010).The Constructivist Criteria for the Quality of Educational Virtual Reality Programming and Three-dimensional Environments, Education Technologies Department, Faculty of Education , King Souad University, p.8. 